\title{
Artikel
}

\section{Beheersen en bestrijden - het voorzorgsbeginsel en informatieplichten bij de onzekere risico's van Q-koorts}

Mr. M.J.W. (Matthijs) Timmer en mr. N. (Nikky) van Triet*

in de Omgevingswet (par. 5), om af te sluiten met een conclusie (par. 6).

\section{Inleiding}

Bij uitspraak van 25 januari 2017 heeft de Rechtbank Den Haag geoordeeld dat de Nederlandse Staat niet aansprakelijk is jegens de (nabestaanden van) slachtoffers van de Q-koortsepidemie. ${ }^{1}$ De Staat heeft zijn rechtsplicht tot het nemen van maatregelen en het informeren van de bevolking niet verzaakt.

In dit artikel zullen wij ingaan op de rol die het voorzorgsbeginsel speelt in het vonnis - zowel met betrekking tot de plicht tot het nemen van maatregelen als de plicht tot het informeren. Onder welke omstandigheden kan worden gesteld dat een overheid (on)voldoende heeft gedaan om haar burgers te beschermen of te waarschuwen, zelfs als niet precies duidelijk is hoe de burgers kunnen worden beschermd?

Eerst bespreken wij de uitspraak van de rechtbank (par. 2). Vervolgens zetten wij het voorzorgsbeginsel en de verschillende verschijningsvormen hiervan uiteen (par. 3), waarna wij ingaan op de (consequenties van) informatieverstrekking door de overheid (par. 4). Als intermezzo zullen wij nog stilstaan bij het voorzorgsbeginsel

* Mr. M.J.W. Timmer is legal counsel bij de Nederlandse Aardolie Maatschappij. Mr. N. van Triet is advocaat bij Van der Feltz advocaten en promovenda aan de Radboud Universiteit Nijmegen op het gebied van overheidsaansprakelijkheid bij informatieverstrekking.

1. Rb. Den Haag 25 januari 2017, ECLI:NL:RBDHA:2017:587, JA 2017/42 m.nt. J.H.G. Verweij-Hoogendijk.

\section{De uitspraak}

\section{$2.1 \quad$ Feitelijk kader}

Van 2007 tot 2010 werd Nederland geteisterd door een Q-koortsepidemie. Q-koorts wordt veroorzaakt door het micro-organisme Coxiella burnetii (ook wel: C. burnetii). Hoewel de meeste besmettingen met Q-koorts niet gepaard gaan met enige symptomen, kan Q-koorts leiden tot verschillende griepachtige ziekteverschijnselen, met in sommige gevallen chronische aandoeningen of de dood tot gevolg.

Q-koorts is een zogenoemde zoönose: een ziekte die van dier op mens wordt overgedragen. Gelet op de manier waarop bij intensieve veeteelt (zoals in Nederland) een zeer grote hoeveelheid dieren dicht op elkaar staat, kan de - van zichzelf toch al zeer besmettelijke - Q-koortsbacterie zich snel over een boerderij verspreiden. Daar komt bij dat Q-koorts bij dieren veelal niet gepaard gaat met unieke symptomen, zodat een besmetting niet direct wordt geconstateerd. Voor verspreiding naar mensen is het vervolgens niet nodig dat het slachtoffer daadwerkelijk in contact komt met een besmet dier. Een besmet stof- of mestdeeltje kan voldoende zijn om tot een menselijke besmetting te leiden. Zeker als de mest wordt uitgereden, is er een goede kans dat de besmette deeltjes een eind buiten de boerderij terechtkomen.

Al (lang) voor 2007 kwam Q-koorts in Nederland endemisch voor: de ziekte is min of meer 'stabiel' aanwezig. Volgens het Rijksinstituut voor Volksgezondheid en 
Milieu (RIVM) ligt het aantal gemelde menselijke besmettingen met Q-koorts in Nederland gemiddeld rond de 20 gevallen per jaar, vooral onder mensen die dagelijks met vee werken. ${ }^{2}$ Van 2007 tot 2011 zijn echter zo'n 4000 besmettingen gemeld en wordt het aantal sterfgevallen vanwege Q-koorts geschat op 74; vóór 2007 zijn geen besmettingen met Q-koorts met een dodelijke afloop geregistreerd. ${ }^{3}$

Vanwege een toename van het antal meldingen van (mogelijke) Q-koortsbesmettingen in 2007 is door verschillende instanties onderzoek gestart. Uit de onderzoeken wordt geen zekerheid verkregen over de precieze bron van de besmettingen, anders dan dat de uitbraak in de omgeving van Herpen is begonnen en zich langzaam over Noord-Brabant verspreidde. In juni 2008 heeft de Minister van Landbouw, Natuur en Voedselkwaliteit (LNV) Q-koorts als besmettelijke dierziekte angewezen, ${ }^{4}$ waarna enkele nadere maatregelen afgekondigd konden worden. ${ }^{5}$ In oktober 2008 is door de Minister van LNV een vrijwillig vaccinatieprogramma voor geiten en schapen afgekondigd. In de zomer van 2009 is geconstateerd dat een zogenaamde tankmelktest een goede indicator kan opleveren voor eventuele Q-koortsbesmettingen op een bedrijf. Het uitvoeren van deze tankmelktest werd verplicht gesteld, ook voor veehouders buiten het besmette gebied. In december 2009 (overigens na een artikel in het NRC Handelsblad en een uitzending van Zembla) werd nog een flink aantal maatregelen afgekondigd om de verspreiding van $\mathrm{Q}_{-}$ koorts tegen te gaan - variërend van strenge monitoringsverplichtingen voor boeren (ook buiten besmet gebied) tot vervoersverboden. Diezelfde maand is begonnen met het preventief afmaken van grote hoeveelheden vee. Deze maatregelen hebben effect gesorteerd, want in juli 2010 kon een deel van de maatregelen worden afgebouwd (terwijl een ander deel nog altijd van kracht is). ${ }^{6} \mathrm{Na} 2010$ was de Q-koortsepidemie ten einde.

\subsection{Toetsingskader}

De Rechtbank Den Haag wordt voor de vraag gesteld of de Staat onrechtmatig heeft gehandeld jegens 297 eisers, allen slachtoffers of nabestaanden van slachtoffers van de Q-koortsepidemie. De gestelde onrechtmatigheid bestaat in (1) het te lang wachten door de Staat met het treffen van adequate maatregelen om de volksgezondheid te beschermen en (2) het door de Staat onvoldoende informeren van eisers over de gevaren van Q-koorts. Eisers verwijzen in het bijzonder naar art. 2 en 8 van het Europees Verdrag tot bescherming van de rechten van

\footnotetext{
Zie www.rivm.nl/Onderwerpen/Q/Q_koorts.

Zie www.rivm.nl/Onderwerpen/Q/Q_koorts.

Regeling van de Minister van LNV van 9 juni 2008, nr. TRCJZ/ 2008/1622, houdende aanwijzing van Q-koorts als besmettelijke dierziekte (Stcrt. 2008, 109)

5. Regeling van de Minister van LNV van 12 juni 2008, nr. TRCJZ/ 2008/1645, houdende maatregelen ter preventie van Q-koorts (Stcrt. 2008, 112).

6. Regeling van de Minister van LNV van 8 juli 2010, nr. 142107, houdende wijziging van de Regeling tijdelijke maatregelen dierziekten in verband met Q-koorts (afbouw Q-koortsmaatregelen) (Stcrt. 2010, 10925).
}

de mens en de fundamentele vrijheden (EVRM) (respectievelijk het recht op leven en bescherming van de persoonlijke levenssfeer) als onderbouwing van hun stellingen.

Voordat de rechtbank ingaat op de merites van de stellingen en vorderingen, zet zij eerst - uiterst leesbaar het toetsingskader uiteen. Voor zowel de eerste als de tweede gestelde onrechtmatige handeling moet worden vastgesteld of op de Staat een rechtsplicht rustte die hij heeft geschonden of verzaakt. Om onrechtmatig handelen aan te nemen is onvoldoende dat wordt vastgesteld dat de Staat meer had kunnen doen. Het moet komen vast te staan dat de Staat ook meer had moeten doen: had de Staat sneller en meer stringente maatregelen moeten nemen, had de Staat eisers meer proactief moeten informeren over de gevaren van Q-koorts? Complicerende factoren bij deze toets zijn ten eerste dat moet worden uitgegaan van de kennis die de Staat op het moment van handelen had of diende te hebben (toetsing ex tunc). Ten tweede komt aan de Staat in dezen een ruime beoordelings- en beleidsvrijheid toe. Deze wordt weliswaar begrensd door de beginselen van behoorlijk bestuur en (hier) art. 2 en 8 EVRM, maar de rechter zal niet in de afwegingen treden die bínnen deze grenzen zijn gemaakt.

Het bepalen van die grenzen is op zich al niet eenvoudig. De rechtbank kan echter het voorzorgsbeginsel als handvat gebruiken. In het navolgende gaan wij nader in op het voorzorgsbeginsel, zodat nu de opmerking volstaat dat de rechtbank hiermee welbeschouwd toetst of de Staat ongeacht alle onzekerheden over de Q-koortsepidemie (oorsprong, wijze van besmetting, enzovoort) tóch voldoende maatregelen heeft genomen.

\subsection{Oordeel}

De rechtbank komt in dit geval tot het oordeel dat de Staat geen op hem rustende rechtsplichten heeft geschonden. Ja, achteraf bezien had op sommige momenten anders of daadkrachtiger kunnen worden opgetreden. De Staat had eerder een vaccinatieprogramma kunnen uitrollen (r.o. 5.114), maar vanwege onduidelijkheden over de risico's en de effectiviteit van het vaccin (laat staan de beschikbaarheid) was de Staat niet gehouden dit te doen. Evenmin valt de Staat te verwijten dat hij niet de voornoemde tankmelktest verplicht stelde (r.o. 5.149). Want hoewel de test achteraf bezien een waardevol instrument bleek, richtte het Q-koortsbeleid zich tot de zomer van 2009 met name op het voorkomen van verdere verspreiding door bijvoorbeeld regels te stellen aan het uitrijden van mest. Pas toen dit ineffectief bleek, bestond er aanleiding om de tankmelktest verplicht te stellen - zeker omdat de tankmelktest zelf met enige vraagtekens was omgeven en zich ook zou richten tot bedrijven die geen gevaar voor de volksgezondheid vormden. Vanuit het voorzorgsbeginsel bezien hoefde de Staat in dit geval dus de minder zekere en meer invasieve maatregel pas te nemen toen duidelijk begon te worden dat met de oorspronkelijke aanpak onvoldoende resultaat werd geboekt. En hoewel de 
rechtbank dit niet expliciet overweegt, betekent het voorzorgsbeginsel ook dat de Staat de op hem rustende rechtsplicht tot bescherming van de volksgezondheid mogelijk wél had geschonden als hij ervoor had gekozen om de tankmelktest onverminderd niet toe te passen vanwege de bijbehorende onzekerheden, ondanks de gebleken ineffectiviteit van de oorspronkelijke aanpak.

Ten aanzien van de beweerdelijk gebrekkige voorlichting vergaat het eisers niet veel beter. Want hoewel het voorzorgsbeginsel, in tandem met art. 2 en 8 EVRM, inderdaad ertoe kan verplichten dat een overheid haar burgers voorlicht over onzekere risico's, is in dit geval niet gebleken dat de Staat deze plicht heeft verzaakt. De informatie die de Staat op www.rijksoverheid.nl en op de website van het RIVM heeft geplaatst, volstaat. Eisers merken nog op dat iemand die een fietstochtje maakt, niet op de website van het RIVM kijkt. Dat laat echter onverlet dat met name www.rijksoverheid.nl het voornaamste communicatiemedium van de Staat is, zodat het hem niet verweten kan worden dat hij (hoofdzakelijk) via deze website heeft gecommuniceerd.

Zo pelt de rechtbank het staatsoptreden methodisch af, om steeds te constateren dat de Staat op basis van de op elk moment beschikbare informatie juist (althans: niet verwijtbaar onjuist) heeft gehandeld in het nemen van maatregelen om de volksgezondheid te beschermen.

Overigens heeft deze kwestie er wel toe geleid dat het Kamerlid Grashoff een amendement heeft ingediend op de aanhangige wijzigingen van de Gezondheids- en welzijnswet voor dieren en de Wet dieren, dat regelt dat slachtoffers van uitbraken van zoönose (zoals Q-koorts) kunnen worden gecompenseerd uit het Diergezondheidsfonds voor geleden schade. ${ }^{7}$ De staatssecretaris van Economische Zaken heeft dit amendement - gelet op het onverplichte karakter van een dergelijke tegemoetkoming en het doel van de diergezondheidsheffingen recentelijk ontraden. ${ }^{8}$

\section{Voorzorgsbeginsel}

Het voorzorgsbeginsel is een relatief recente vinding, waarschijnlijk voor het eerst in 1971 in het Duitse recht gecodificeerd. ${ }^{9}$ De meest bekende versie van het voorzorgsbeginsel stamt evenwel uit de Verklaring van Rio van de United Nations Conference on Environment and Development (UNCED) uit 1992, luidend als volgt:

'In order to protect the environment, the precautionary approach shall be widely applied by States according to their capabilities. Where there are threats of serious or irreversible damage, lack of full scientific certainty shall not be used as a reason for

Kamerstukken II 2016/17, 34 570, nr. 12

8. Kamerstukken II 2016/17, 34 750, nr. 14

9. M. Kloepfer, Umweltrecht, München: Beck 2004, p. 173. postponing cost-effective measures to prevent environmental degradation.'

In datzelfde jaar wordt het voorzorgsbeginsel in art. 130R van het Verdrag van Maastricht (art. 174 na omnummering; thans art. 191 van het Verdrag betreffende de werking van de Europese Unie (VWEU)) opgenomen als pijler van het Europese milieurecht, overigens zonder het voorzorgsbeginsel te definiëren. Dit laatste lijkt enigszins symptomatisch voor het voorzorgsbeginsel, nu in het internationale (milieu)recht zo'n twintig definities van het beginsel in omloop zijn, ${ }^{10}$ in aanvulling op de vijftien verdragen die het beginsel noemen, maar niet definiëren. ${ }^{11}$ Wel zijn er drie elementen die consequent terugkeren: (1) het voorzorgsbeginsel heeft betrekking op dreigende (milieu)schade; (2) er is onzekerheid of de schade zal intreden; en (3) ondanks die onzekerheid over het intreden van schade moet enige vorm van actie worden ondernomen. De precieze actie kan vervolgens worden gekozen aan de hand van de omvang van de dreigende schade en de mate van (on)zekerheid omtrent het intreden ervan. Effectiviteit en proportionaliteit van de actie zijn het uitgangspunt, ${ }^{12}$ maar voor het overige heeft de betrokken overheid veel beleidsvrijheid. ${ }^{13}$ Als wij dan zelf tot een definitie van het voorzorgsbeginsel moeten komen, zou deze luiden: de plicht tot het ondernemen van proportionele en effectieve actie tegen ernstige of onomkeerbare (milieu)schade, indien op basis van de best beschikbare metenschap deze schade te vermoeden, maar niet te garanderen valt.

Het voorzorgsbeginsel wordt inmiddels ook buiten het milieurecht steeds vaker toegepast. Interessant voor het doel van deze bijdrage is dat het voorzorgsbeginsel ook een rol begint te spelen in de bescherming van mensenrechten, in het bijzonder art. 2 EVRM (recht op leven) en art. 8 EVRM (bescherming van de persoonlijke levenssfeer). Het Europees Hof voor de Rechten van de Mens (EHRM) heeft tot op heden al meermaals aangenomen dat een staat - onder omstandigheden - zijn burgers dient te beschermen tegen onzekere risico's. Anders gezegd, zelfs als niet duidelijk is of een bepaald gevaar zal intreden, kan op een staat tóch de (rechts)plicht rusten tot het treffen van maatregelen. Als opgemerkt, is de aard van de te nemen maatregelen afhankelijk van de mate van onzekerheid en de consequenties als het onzekere risico zich verwezenlijkt.

Een van de eerste zaken waarin het EHRM zo oordeelde (zie verder ook par. 4), is Tatar/Roemenië. ${ }^{14}$ De zaak draaide om een oppervlaktewaterverontreiniging met cyanide, door een fout van een (goud)mijnbouwbedrijf.

10. C.R. Sunstein, Precautions against What? Perceptions, Heuristics and Culture, in: J.B. Wiener e.a. (red.), The Reality of Precaution, Washington, DC: RFF Press 2011, p. 495.

11. A. Trouwborst, Precautionary Rights and Duties of States (diss. Utrecht), Leiden: Martinus Nijhoff Publishers 2006, p. 22.

12. Vgl. bijv. Internationaal Zeerechttribunaal (ITLOS) 27 augustus 1999, Southern Bluefin Tuna Cases.

13. Europese Commissie, Mededeling van de Commissie over het voorzorgbeginsel (COM(2000)1)

14. EHRM 27 januari 2009, 67021/01 (Tatar/Roemenië). 
De Roemeense overheid heeft vervolgens nagelaten om maatregelen te nemen: er is geen onderzoek verricht naar de risico's van het gebruik van cyanide voor goudertswinning, het publiek is niet op de hoogte gesteld van de mogelijke risico's van deze wijze van winning (zowel voor als na de verontreiniging niet) en de Roemeense overheid heeft het mijnbouwbedrijf niet opgedragen om bijvoorbeeld het gebruik van cyanide te staken. Gegeven deze omstandigheden heeft de Roemeense overheid onvoldoende gedaan om haar bevolking te beschermen tegen de mogelijke risico's door het gebruik van cyanide. Het EHRM stelt een schending van art. 8 EVRM vast. Dát de risico's onzeker waren, blijkt onder meer uit het feit dat klager niet in staat is gebleken om de gezondheidsklachten van zijn zoon - die aanleiding vormden tot de procedure - aantoonbaar in verband te brengen met de cyanideverontreiniging.

Deze 'voorzorgsbenadering' is een terugkerend patroon in de uitspraak van de Rechtbank Den Haag, zowel op het gebied van de maatregelen ter bestrijding van de $\mathrm{Q}-$ koorts als op het gebied van het informeren van de burger. Telkenmale beoordeelt de rechtbank met welke mate van onzekerheid de Staat te maken had (onder andere op het gebied van de oorzaak van de besmetting, de wijze van verspreiding en de effectiviteit van bestrijdingsmaatregelen) en of de Staat binnen de beleidsvrijheid die deze onzekerheid biedt, tóch de maatregelen heeft genomen die gevergd konden worden. Dat niet elke maatregel even effectief bleek, is tot op zekere hoogte inherent aan handelen conform het voorzorgsbeginsel - zolang bij de gebleken ineffectiviteit maar een ándere (al dan niet onzekere) weg wordt ingeslagen. En de Staat heeft dit consequent gedaan, totdat op enig moment een succesvolle aanpak is gevonden en de Qkoortsbesmettingen konden worden ingedamd.

Wij merken zekerheidshalve nog op dat hoewel het voorzorgsbeginsel een van origine bestuursrechtelijk beginsel is, het niet is uitgesloten dat schending van het voorzorgsbeginsel kan leiden tot civielrechtelijke aansprakelijkheid. ${ }^{15} \mathrm{Op}$ het moment dat het voorzorgsbeginsel dwingt tot actie (ondanks onzekerheid), valt ons inziens goed te betogen dat hiermee ook een zorgplicht voor de overheid in het leven wordt geroepen. Schending hiervan zou kunnen leiden tot onrechtmatig handelen - het element dat de omvang van de verplichting tot handelen afhangt van de onzekerheid en de consequenties bij verwezenlijking van het risico riekt wat ons betreft zelfs al naar de Kelderluik-criteria. ${ }^{16}$

15. Zie o.a. M. Olaerts, Van aansprakelijkheid tot voorzorg. Enige beschouwingen omtrent de toenemende betekenis van het voorzorgsbeginsel in verhouding tot het aansprakelijkheidsrecht, AV\&S 2003/114 en S. Franken, Voorzorg: beginsel in het aansprakelijkheidsrecht?, NJB 2008/1682. Minder overtuigd: Bauw, in: GS Onrechtmatige daad, aant. VIII 6.3.10 Het voorzorgsbeginsel.

16. HR 5 november 1965, ECLI:NL:HR:1965:AB7079, NJ 1966/136.

\section{Onvoldoende informatie- verstrekking door de Staat?}

\subsection{Gerichte en ongerichte informatie- verstrekking}

De tweede klacht van eisers zag op het vermeend onvoldoende informatie verstrekken door de Staat.

Wanneer een overheid uit zichzelf informatie verstrekt, spreken we van actieve verstrekking. In het kader van de Q-koorts heeft de Staat informatie verstrekt die aan een niet duidelijk afgebakende groep mensen is gericht: het was voor de Staat niet duidelijk wie de informatie zou ontvangen en wat mensen hiermee zouden doen. De informatie kwalificeert daarmee als algemene voorlichting (in dit geval op de website van de Rijksoverheid) die actief is verstrekt.

De literatuur en jurisprudentie maken een onderscheid tussen gerichte en ongerichte informatie. ${ }^{17}$ De mate van gerichtheid betreft de vraag voor wie de verstrekte informatie bedoeld is. Gerichte informatie is specifiek - eventueel naar aanleiding van een concreet verzoek en is gericht tot bepaalde (groepen van) individuele burgers. Denk aan informatie die een burger verkrijgt naar aanleiding van een individueel gesprek met een ambtenaar over de mogelijkheden tot bebouwing op zijn perceel of een mededeling van de overheid aan een duidelijk omlijnde groep mensen, bijvoorbeeld aanvragers van een specifieke subsidie. ${ }^{18}$ De doelgroep bij ongerichte informatie is daarentegen niet duidelijk afgebakend. Sprake is daarbij van informatieverstrekking ten behoeve van 'iedere' burger of van een grote groep. Het voornaamste verschil is dat gerichte informatie van de overheid aan burgers in het algemeen wordt gebruikt in aan de overheid kenbare specifieke situaties. Zodoende kan de overheid verwachten dat een burger in deze voor de overheid kenbare situatie op de verstrekte informatie afgaat (hetgeen overigens niet impliceert dat de burger er daarmee ook in elk geval gerechtvaardigd op mag vertrouwen). ${ }^{19} \mathrm{Bij}$ ongerichte informatie bezit de overheid - gezien de grote doelgroep - deze kennis niet. De gerichtheid is dus zowel vanuit het perspectief van de ontvanger als vanuit het perspectief van de verstrekker van belang: de ontvanger zal eerder vertrouwen op informatie die gericht aan hem wordt verstrekt en de verstrekker moet rekening houden met het feit dat de burger op de gerichte informatie af zal gaan.

17. Zie bijv. J.M. Barendrecht e.a., Overheidsaansprakelijkheid voor informatieverstrekking, Den Haag: Boom Juridische uitgevers 2002, p. 31-38, M.W. Scheltema \& M. Scheltema, Gemeenschappelijk recht. Wisselwerking tussen publiek- en privaatrecht, Deventer: Kluwer 2013, p. 410, B.P.M. van Ravels, Overheidsaansprakelijkheid voor informatieverstrekking, O\&A 2004/43 en B.J.P.G. Roozendaal, Enkele opmerkingen over actieve en passieve informatieverstrekking, O\&A 2008/102.

18. Zie voor het aansprakelijk stellen van de overheid als gevolg van deze informatie HR 25 mei 2012, NJ 2012/340 ('s-Hertogenbosch/Van Zoggel).

19. Scheltema \& Scheltema 2013, p. 410 en T.A. Cramwinckel \& N. van Triet, Het dispositievereiste en het vertrouwensbeginsel bij toezeggingen en inlichtingen, NTB 2016/16, onder 2.1. 


\subsection{Gevolgen onderscheid gerichte en ongerichte} informatieverstrekking

Op grond van de kenbaarheid voor de overheid over wat de ontvanger met de informatie zal doen, kan worden gekeken naar de voorzienbaarheid van de door de informatieverstrekking mogelijk veroorzaakte schade en (de mogelijkheid tot) het nemen van voorzorgsmaatregelen om die eventuele schade te voorkomen. ${ }^{20}$ Met betrekking tot voorlichting kan worden gewezen op het duidelijk maken welke betekenis aan de informatie kan worden ontleend (denk aan het vermelden van een foutenmarge), en waarschuwingen (in het algemeen) voor ander gebruik dan waarvoor de informatie oorspronkelijk is gegeven. Deze voorzorgsmaatregelen kosten niet veel en kunnen dan ook snel van een overheid gevergd worden. ${ }^{21}$

Het onderscheid tussen gerichte en ongerichte informatievoorziening werkt door in de mogelijkheden om de overheid aansprakelijk te stellen bij gebreken in de informatievoorziening. Dat gerichte informatie - gezien de op het specifieke geval toegespitste informatie, de voorzienbaarheid van de eventuele schade en de mogelijkheden van de overheid om voorzorgsmaatregelen te nemen - tot aansprakelijkheid kan leiden, is onomstreden..$^{22}$ Overheidsaansprakelijkheid vanwege onjuiste of onvolledige informatieverstrekking is dan ook meestal het gevolg van gerichte - individuele - informatie. Dit ligt anders bij ongerichte informatie. ${ }^{23}$ In de literatuur wordt aangenomen dat dit soort informatie over het algemeen niet makkelijk tot aansprakelijkheid kan leiden, ${ }^{24}$ juist omdat het voor de overheid lastig is in te schatten wat burgers met de informatie gaan doen en omdat het een (te) zware opgave zou zijn voor dat soort informatie voorzorgsmaatregelen te nemen. ${ }^{25} \mathrm{Er}$ is zelfs betoogd dat aansprakelijkheid slechts kan ontstaan in geval van gerichte informatie. ${ }^{26}$ Uit de jurisprudentie

20. Van Ravels 2004.

21. Barendrecht e.a. 2002, p. 16.

22. Zie bijv. Barendrecht e.a. 2002, p. 31 e.v. en Scheltema \& Scheltema 2013, p. 410-417

23. Zie P. Nicolaï, Beginselen van behoorlijk bestuur (diss. Amsterdam UvA), Deventer: Kluwer 1990, p. 365-366, waarin wordt beschreven hoe aan algemene informatie weinig gerechtvaardigd vertrouwen kan worden ontleend.

24. Zie bijv. Barendrecht e.a. 2002, p. 36-38, R.J.N. Schlössels \& S.E. Zijlstra, Bestuursrecht in de sociale rechtsstaat, Deventer: Kluwer 2010, p. 1454-1455 en Scheltema \& Scheltema 2013, p. 411-415. Zie S.A.L. van de Sande, Overheidsaansprakelijkheid voor het verstrekken van ongerichte informatie, in: T.W. Franssen e.a. (red.), Op het grensvlak (Van Ravels-bundel), Den Haag: IBR 2014 voor het betoog dat terughoudendheid bij het nemen van aansprakelijkheid alleen zou moeten gelden voor onvolledige ongerichte informatie en niet bij onjuiste ongerichte informatie.

25. Anders: N.A. de Vos, Europeanisering van het vertrouwensbeginsel (diss. Utrecht), Den Haag: Boom Juridische uitgevers 2011, p. 296 e.v. Zij redeneert dat vanwege het feit dat algemene inlichtingen niet op een concrete casus slaan, er geen besluit in het vooruitzicht wordt gesteld met betrekking tot een concreet geval (hetgeen wel het geval is bij aan de betrokkene persoonlijk gegeven informatie). Dat zou de reden zijn dat vertrouwen op algemene inlichtingen over het algemeen niet gehonoreerd wordt.

26. Barendrecht e.a. 2002, p. 37 en de noten aldaar. De reden daarvoor wordt gezocht in het voorkomen dat de overheid anders te vaak zou volstaan met het geven van te summiere informatie. volgt als vuistregel dat ansprakelijkheid bij ongerichte informatie alleen aangenomen kan worden wanneer de overheid onjuiste informatie zou verstrekken over eigen bevoegdheden, beleid of regelgeving. ${ }^{27}$

\subsection{Toepassing op de Q-koorts-zaak}

In onderhavig geval heeft de Rechtbank Den Haag gekeken naar de door de Staat verstrekte informatie en geconcludeerd dat de Staat hierbij niet onrechtmatig heeft gehandeld (r.o. 5.153 e.v.). Uit jurisprudentie van het EHRM leidt de rechtbank af dat voor de Staat een verplichting gold tot ambtshalve informatieverstrekking om burgers te informeren over de gezondheidsrisico's (r.o. 5.155-5.160). Bij de invulling van deze plicht heeft de Staat een margin of appreciation. De rechtbank oordeelt dat de Staat niet willens en wetens onjuiste of onvolledige informatie zou hebben verstrekt. Vervolgens beoordeelt de rechtbank de (telkens bijgewerkte) website van de Rijksoverheid met informatie en toetst vervolgens of die informatie als onjuist of onvolledig kan worden gekwalificeerd. Volgens de rechtbank heeft de Staat voldaan aan de taak van publieksvoorlichting (r.o. 5.169).

In dit oordeel van de rechtbank speelt het voorzorgsbeginsel eveneens een rol. Moet de burger immers worden geinformeerd over mogelijke risico's waaraan hij kan worden blootgesteld? Blijkens de jurisprudentie van het EHRM kan dat inderdaad het geval zijn. De zaak Vilnes/Noorwegen draaide specifiek om de verplichting tot het informeren over onzekere risico's door het openbaar maken van zogenaamde decompressietabellen. ${ }^{28}$ Het onvoldoende informeren van beroepsduikers (in overheidsdienst) over de - toentertijd - onduidelijke gevaren van decompressie, waardoor verschillende duikers arbeidsongeschikt zijn geraakt, is in strijd met art. 8 EVRM bevonden. Hier speelde het voorzorgsbeginsel een grote rol: ondanks dat niet duidelijk was wat de gevolgen van decompressie precies zouden zijn, had de Noorse overheid de duikers op zijn minst moeten voorzien van decompressietabellen, aan de hand waarvan zij zelf enige inschatting hadden kunnen maken van de risico's en met informed consent hun werk konden uitvoeren. Deze uitspraak bouwt, aldus r.o. 235-236, voort op Guerra/Italië, waarin eveneens werd aangenomen dat op een overheid de plicht kan rusten om burgers te informeren over onzekere risico's, op basis waarvan de burgers vervolgens zelf kunnen bepalen of zij al dan niet dit risico durven an te gaan. ${ }^{29}$ In beide gevallen stelde het EHRM echter geen concrete eisen aan de manier waarop de betrokkenen moesten worden geïnformeerd zo is niet uitgesloten dat bijvoorbeeld het verstrekken van decompressietabellen ongericht had kunnen plaatsvinden (te denken valt aan plaatsing op een interne web-

27. Barendrecht e.a. 2002, p. 37 en Scheltema \& Scheltema 2013 p. 416-417.

28. EHRM 5 december 2013, nr. 52806/09 en 22703/10, AB 2014/105 m.nt. T. de Jong, NJ 2015/129 m.nt. E.A. Alkema (Vilnes/Noorwegen).

29. EHRM 19 februari 1998, nr. 14967/89 (Guerra/Italië). 
site, of het in alle postvakjes achterlaten van de tabellen met een algemene, begeleidende brief).

Wanneer op de overheid een actieve informatieplicht rust, is het belangrijk dat de burgers op basis van de verstrekte informatie zelf een afweging kunnen maken. Wanneer het informatie betreft die voor (een groep) specifieke burgers relevant is, zouden wij ons dan ook kunnen voorstellen dat de overheid niet wil volstaan met ongerichte informatieverstrekking. Voor zover de overheid kiest voor ongerichte informatieverstrekking, zou de informatie in ieder geval dusdanig volledig moeten zijn, dat iemand op grond daarvan een degelijke afweging kan maken. Op grond van de EHRM-jurisprudentie menen wij dat inhoud boven vorm gaat: het lijkt er niet op dat een overheid niet zou mogen volstaan met ongerichte informatieverstrekking, als deze maar volledig genoeg is.

Ten aanzien van het informeren van de burgers valt uit de EHRM-jurisprudentie immers op te maken dat een lidstaat bovenal tegen een schending van mensenrechten kan aanlopen als hij de bevolking in het geheel niet informeert over onzekere risico's en de bevolking geen deugdelijke risicoafweging kan maken. Het EHRM stelt evenwel geen eisen aan de wijze waarop een staat met de bevolking communiceert (dit zal veelal binnen de margin of appreciation vallen). Het verbaast daarom ook niet dat de Rechtbank Den Haag geen bezwaren heeft gezien in de keuze van de Staat om via de website van de Rijksoverheid informatie te verspreiden.

Als terzijde merken wij in het kader van de eventuele plicht tot het nemen van preventieve maatregelen (waaronder informeren) nog het volgende op. Om te komen tot een dergelijke verplichting uit hoofde van het EVRM moet in ieder geval sprake zijn van een (dreigende) inbreuk op de door art. 2 en/of 8 EVRM beschermde rechten en van kennis bij de bewuste overheid van de (dreigende) inbreuk op deze rechten. ${ }^{30} \mathrm{Op}$ grond van EHRM-jurisprudentie geldt daarenboven het Osmancriterium. ${ }^{31}$ Dit criterium betekent dat ingeval (1) kennis over een dreigende situatie voor een afgebakende groep mensen in een concrete situatie aanwezig is en (2) deze situatie een reëel en onmiddellijk risico vormt voor het leven en/of de gezondheid van één of meer specifieke individuen, de overheid moet overgaan tot maatregelen die naar redelijke verwachting tot afwending van het risico leiden. ${ }^{32}$

Op grond van hetgeen wij hierboven uiteen hebben gezet over de betekenis van het voorzorgsbeginsel in de Q-koorts-zaak en de op de Staat rustende informatieplicht als gevolg daarvan, menen wij dat in dit geval niet aan het Osman-criterium wordt toegekomen. Het ontbreken van de kennis bij de Staat over de verspreiding van de ziekte maakte dat de mogelijkheden om effectieve

30. E.C. Gijselaar \& E.R. de Jong, Overheidsfalen en het EVRM bij ernstige bedreigingen voor de fysieke veiligheid, NTBR 2016/6.

31. EHRM 28 oktober 1998, nr. 23452/94 (Osman/Verenigd Koninkrijk).

32. Gijselaar \& De Jong 2016. maatregelen in de vorm van informatieverstrekking te nemen werden beperkt. Wanneer wél sprake zou zijn geweest van zekerheid over de verspreiding en preventie van Q-koorts, lijkt het ons niet onaannemelijk dat wél een plicht tot meer concrete informatieverstrekking op de overheid zou rusten. Met inachtneming van het Osman-criterium zou in die situatie wellicht ook kunnen worden gevergd dat de informatieverstrekking gericht is - maar zolang het voorzorgsbeginsel een rol blijft spelen binnen het afwegingskader (en dus niet aan het Osmancriterium wordt toegekomen) gaan zulke eisen ons inziens te ver.

\section{Omgevingswet en voorzorgsbeginsel?}

$\mathrm{Nu}$ het voorzorgsbeginsel een van oorsprong milieurechtelijk beginsel is, kunnen wij niet zomaar de vraag passeren welke rol het voorzorgsbeginsel zal krijgen in de Omgevingswet. Pleitbezorgers van een voorzorgsbeginsel in de Algemene wet bestuursrecht hebben nog altijd niet hun zin gekregen, ${ }^{33}$ maar in ieder geval bestaat met de Omgevingswet (hierna ook: Ow) de kans om het voorzorgsbeginsel als een van de fundamenten van het omgevingsrecht aan te wijzen. Zo zou afdeling 1.3 (de zorgplicht) hiervoor een logische plaats zijn art. $1.7 \mathrm{Ow}$ (de zorgplicht ook in geval van een vermoeden van nadelige gevolgen) raakt het voorzorgsbeginsel al bijna. ${ }^{34}$ Helaas heeft de wetgever deze kans niet ten volle aangegrepen.

In het voorstel van de Omgevingswet dat aan de Tweede Kamer is voorgelegd, ontbrak het voorzorgsbeginsel geheel, hoewel in de memorie van toelichting het voorzorgsbeginsel tweemaal als richtinggevend beginsel is benoemd. ${ }^{35}$ In het verslag valt vervolgens vijfmaal de vraag te lezen waarom niet voor een codificatie van het voorzorgsbeginsel is gekozen. ${ }^{36}$ In de nota naar aanleiding van het verslag wordt volstaan met de opmerking dat het voorzorgsbeginsel toch al wordt toegepast en dat de (bestuurs)rechter hieraan kan toetsen over de band van het motiveringsbeginsel. ${ }^{37}$ Het zou daarom niet nodig zijn om het voorzorgsbeginsel expliciet te benoemen, hoewel het hier gaat over een wet waarin de wetgever het wel nodig heeft geacht om het doel van de wet op te nemen (art. 1.4 Ow). Los van twijfels die wij hebben

33. O.a. R. van der Velde, Voorzorg in het bestuursrecht, NJB 2015/351 en M.J.W. Timmer, Het voorzorgsbeginsel als algemeen beginsel van behoorlijk bestuur?, AA 2014, p. 601

34. De zorgplicht van art. 1.7 Ow gaat over het handelen waarvan de nadelige gevolgen bekend zijn of vermoed worden. De onzekerheden waarop het voorzorgsbeginsel ziet, kunnen ook bestaan vóór het vermoeden van nadelige gevolgen.

35. Kamerstukken II 2013/14, 33 962, nr. 3, p. 37 en 367, samen met het beginsel van preventief handelen, het beginsel dat milieuaantastingen bij voorrang aan de bron moeten worden bestreden, en het beginsel dat de vervuiler betaalt.

36. Kamerstukken II 2014/15, 33 962, nr. 6, p. 13 en 19 (PvdA), p. 20 (ChristenUnie), p. 30 (SP) en p. 48 (D66).

37. Kamerstukken II 2014/15, 33 962, nr. 12, p. 77 
bij deze benadering ${ }^{38}$ - kan een besluit bijvoorbeeld zonder meer worden vernietigd wanneer de omgang met onzekere risico's onvoldoende gemotiveerd is? - laat de wetgever ook een goede kans liggen om het belang van het voorzorgsbeginsel te benadrukken.

Niettemin heeft de regering zich de kritiek wel ten dele aangetrokken. Art. $3.3 \mathrm{Ow}$, toegevoegd bij de tweede nota van wijziging, ${ }^{39}$ bepaalt dat bij het opstellen van een omgevingsvisie onder meer rekening wordt gehouden met het voorzorgsbeginsel. De omgevingsvisie is evenwel primair een beleidsmatig instrument - zo is de gemeenteraad bij het vaststellen van een omgevingsplan niet gebonden aan de gemeentelijke omgevingsvisie, laat staan aan een omgevingsvisie van een andere overheid. Wel zal bij de vaststelling van bijvoorbeeld het omgevingsplan een afwijking van een omgevingsvisie deugdelijk moeten worden gemotiveerd. Daarmee is het voorzorgsbeginsel weliswaar toch in de Omgevingswet beland, maar zal een rechterlijke toetsing eraan onverminderd over de band van het motiverings- en zorgvuldigheidsbeginsel gespeeld moeten worden.

Mogelijk interessanter is de zelfbinding die de wetgever zich oplegt in art. 23.6 Ow (althans, de zelfbinding die bij amendement door de Tweede Kamer is opgelegd ${ }^{40}$ ): in de nota van toelichting bij elke $A M v B$ waarop de voorhangprocedure van art. $23.5 \mathrm{Ow}$ van toepassing is, zal steeds moeten worden toegelicht hoe rekening is gehouden met het voorzorgsbeginsel. De bestuursrechter kan hier allicht weinig mee aanvangen, maar het biedt ons inziens wel een zekere geruststelling dat in ieder geval bij de regels die op nationaal niveau worden vastgesteld, het voorzorgsbeginsel tot het denkkader van de wetgever heeft moeten behoren.

Overigens zal de Omgevingswet na de Aanvullingswet natuur Omgevingswet nog een aparte verankering van het voorzorgsbeginsel krijgen, namelijk het voorzorgsbeginsel zoals dat volgt uit art. 6 lid 3 van de Habitatrichtlijn (thans opgenomen in art. 2.7 van de Wet natuurbescherming en voorheen in art. 19d van de Natuurbeschermingswet 1998). 'Dit' voorzorgsbeginsel heeft echter specifiek betrekking op de verbodsbepaling in die artikelen en vormt geen algemene beleidspijler zoals in art. $191 \mathrm{VWEU}$.

\section{Conclusie}

De uitspraak van de Rechtbank Den Haag is een prachtige uiteenzetting van de wijze waarop (en de omstandigheden waarin) het voorzorgsbeginsel een rol kan en moet spelen bij de beheersing en bestrijding van onzekere risico's door de overheid - in dit geval de Q-koortsepidemie.

We hebben vastgesteld dat van een overheid ook bij onzekere risico's proactief optreden wordt verwacht, zelfs als niet op voorhand vaststaat dat dit optreden ook effect zal sorteren. Het is vervolgens aan die overheid om voortdurend te evalueren of de onzekerheid omtrent de risico's kan worden verminderd en om nauwgezet te monitoren of de genomen maatregelen aanslaan. Zo niet, dan zal een volgend pakket aan maatregelen moeten worden uitgerold. Vanuit het voorzorgsbeginsel bezien is de grote zonde die een overheid kan begaan, 'niets doen omdat we het toch niet zeker weten'. Dit geldt niet alleen voor de aanpak van het onzekere risico, maar ook voor het op de hoogte houden van de burger - onzekerheid kan lang niet altijd doorslaggevend zijn om burgers niet over mogelijke gevaren te informeren. Onder bepaalde omstandigheden moet een overheid dan ook actief informatie verstrekken, zodat burgers zelf een risicoafweging kunnen maken. Daarbij hebben wij opgemerkt dat de overheid deze informatie zowel ongericht als gericht kan verstrekken. Dit zou anders kunnen worden zodra duidelijk is welke duidelijk afgebakende groep burgers een (mogelijk) risico loopt.

Vervolgens moeten we ook constateren dat áls een overheid afdoende proactief optreedt, zij daarin ook een aanzienlijke beleids- en beoordelingsvrijheid heeft. Gelet hierop voorzien wij niet dat een overheid eenvoudig aansprakelijk gesteld kan worden als zij de verkeerde maatregelen neemt (mits niet met zekerheid ten tijde van het handelen de juiste maatregel aangewezen kon worden).

Hoewel zonder twijfel uiterst teleurstellend voor de slachtoffers van de Q-koorts, past de uitspraak van de Rechtbank Den Haag daarom wel netjes binnen de overige jurisprudentie omtrent het voorzorgsbeginsel. 